\title{
Inventory Control of Drugs Listed in Private Health Insurance at Pharmacies in South Tangerang using ABC Analysis
}

\author{
Andriyani Rahmah Fahriati ${ }^{1}$, Dwi Sari Suryatiningrum ${ }^{2}$, Tanti Juwita Saragih ${ }^{1}$
}

${ }^{1}$ Clinical and Community Pharmacy, Widya Dharma Husada Tangerang

School of Health Science, Tangerang Selatan. Tangerang, South Tangerang, Banten, Indonesia

${ }^{2}$ Diploma of Pharmacy, Kharisma Persada School of Health Science, Jakarta, Indonesia

\begin{abstract}
Inventory control in pharmacies must be appropriately and effectively maintained to promote continuous drug affordability and availability in the community within the healthcare delivery system. Initially, effective drug planning and procurement are essential to attain proper drug selection, quantification, and procurement based on the consumption pattern with good economic impact and clinical value. Therefore, the ABC analysis method is suggested to be implemented to optimize efficient budget and effective drug planning. This study aimed to investigate the planning and procurement process of drug listed in private health insurance using the $\mathrm{ABC}$ analysis method in the pharmacies $\mathrm{X}$ and $\mathrm{Y}$. This study was non-experimental study with descriptive analysis utilizing qualitative and quantitative data. Drug enlisted in the private insurance data in 2019 were taken retrospectively. Based on the $\mathrm{ABC}$ analysis results, in pharmacy store $\mathrm{X}$, drug listed in group A showed 83 items with the highest investment value of $86.38 \%$, group B showed 102 items with $15.61 \%$, and group C showed 129 items with the lowest investment value of $4.79 \%$. Meanwhile, in pharmacy $\mathrm{Y}$, drug listed in group A showed 87 items with the highest investment value of $89.62 \%$, group B showed 100 items with $7.62 \%$, and group C showed 134 items with the lowest investment value of $2.76 \%$. Using the $\mathrm{ABC}$ analysis to manage the drug inventory system could assist pharmacy store $\mathrm{X}$ and $\mathrm{Y}$ in planning the procurement of drug listed in the private healthcare insurance effectively. Also, taking into account the values of consumption and investment are obtained efficiently.
\end{abstract}

Keywords : Pharmacy management, pharmacy stores, planning and procurement control, $\mathrm{ABC}$ analysis

\section{Introduction}

Inventory control is a scientific system designated to know what and how much items should be ordered, and when the order should be made and how much to stock. With the limitation of the available drug spending budget, it is important to achieve the right drug selection and drug quantity in the drug planning and procurement process in the pharmacies. In order to support the condition, there are several important things that must be considered including the pattern of drug consumption and the inventory storage cost which should be kept as low as possible. ${ }^{1-4}$ Therefore, drug inventory control is very essential to be maintained properly.

Corresponding author:Andriyani Rahmah Fahriati. Clinical and Community Pharmacy, SWidya Dharma Husada Tangerang School of Health Science, South Tangerang, Banten, Indonesia. Email: andriyanirahmah@wdh.ac.id Received: 6 january 2021 Revised: 15 March 2021 Published: 1 April 2021 
According to the Regulation of the Republic Indonesia Ministry of Health no. 73 of 2016 regarding the standard of pharmaceutical service at the pharmacy, pharmaceutical management activities at the pharmacy are initiated from planning the pharmaceutical supply then followed by procuring, receiving, storing, destroying, controlling, recording and reporting processes. ${ }^{5}$ In addition, drug procurement activities include prepartion of essential drug list, assessment of the quantity of the drug needed, quality assurance from suppliers, procurement step, supply chain management and prompt payment to suppliers. ${ }^{3,4}$ These activities are needed to be conducted appropriately at the pharmacy in order to promote continuous drug affordability and availability in the community within the healthcare delivery system. As the initial steps, drug planning, and procuring are the most essential process that are needed to be managed effectively, hence the clinical aspect and the economic aspect of the drug will be both achieved. ${ }^{6-8}$

The ABC analysis is a simple method used to identify items which give a significant effect on overall inventory cost, while also clasifying the item into three stock categories with different controls and management. ${ }^{9}$ The three categories of the $\mathrm{ABC}$ analysis are group A with highly attention item, and group B and $\mathrm{C}$ with less tightly controlled than group A. ${ }^{10}$ This method will represent objective analysis of the drug priority in the inventory control while also will support the effective planning and procurement process in the pharmacies. ${ }^{11}$ The ABC analysis is considered to be effective method in controlling drug supply because the analysis will show the priority based on the investment value, critical value, and the highest consumption value. ${ }^{12,13}$

In addition, out of stock drug is often encountered in the pharmacies that leads to the unfulfillment of patient necessity of the drug, unable to promote continuous drug availability in the community. Unplanned drug procurement will lead to unpredicted cost in ordering drug. ${ }^{14}$ Therefore, to avoid the issue, the $\mathrm{ABC}$ analysis are necessary to be used to obtain the right drug selection and drug quantity based on the pattern of drug consumption especially for drug listed in the JKN (national health insurance in Indonesia) and also to provide continuous drug availability in healthcare facility.

Pharmacies $\mathrm{X}$ and $\mathrm{Y}$ in Tangerang serve various types of health insurance, including $\mathrm{Z}$ commercial health insurance ( $\mathrm{Z}$ insurance). Based on the preliminary observation, both of pharmacies had problems related to drug procurement management, especially for drug listed in the formularium of $\mathrm{Z}$ insurance. The planning and procurement of drug listed in the formularium of $\mathrm{Z}$ insurance were not using an objective or scientific analysis, but were only estimated by the staffs. Thus, lack of drug planning and procurement analysis in these pharmacies lead to drug out of stock and unability to fulfill the drug needs of the patient. Hence, this study was conducted to investigate the inventory control by the drug planning and procurement process for the drug listed in the formularium of $\mathrm{Z}$ insurance using the $\mathrm{ABC}$ analysis.

\section{Methods}

This data obtained for this study was from the list and number of drug consumed by the patients and list of drug prices during January to December 2019 in the pharmacies (X and Y) located in South Tangerang, Banten, Indonesia. The pharmacies in Tangerang were chosen due to the used of various types of health insurance, including $\mathrm{Z}$ insurance.

This study was non-experimental with descriptive analysis utilizing qualitative 
and quantitative data. Quantitave data was obtained from drug listed in the formularium of $\mathrm{Z}$ insurance which was taken retrospectively while qualitative data was obtained by interviewing the pharmaceutical care staffs in the pharmacies.

Population used in the study was all of the drug available in the Pharmacy $\mathrm{X}$ and $\mathrm{Y}$ in 2019, in which pharmacy X with 1458 items and pharmacy Y with 1614 drug items. The sample of this study was drug listed in the formularium of $\mathrm{Z}$ insurance in the pharmacy $\mathrm{X}$ and $\mathrm{Y}$ with 314 and 321 items, respectively. Drugs were not differentiated into categories, drugs studied were based on all types of drugs covered by $\mathrm{Z}$ insurance. Drugs were only divided based on the category of consumption and investment value from the highest to the lowest value.

The ABC analysis is a method of making groups or classifications based on the ranking of values from highest to lowest value, this management technique is useful for increasment, effectiveness, and efficiency of inventory. $\mathrm{ABC}$ analysis is divided into 3 major groups called groups $\mathrm{A}, \mathrm{B}$ and $\mathrm{C}$. $\mathrm{ABC}$ analysis could help the management to determine the appropriate control for each classification of drugs and which drug should be prioritized to increase efficiency and reduce costs. ${ }^{15}$

The obtained data were reviewed and analyzed as MS excel spreadsheet of the pharamcies. The $\mathrm{ABC}$ analysis of drugs purchased or inventory was conducted. Each item was arranged in descending order. The cumulative cost was then calculated. The cumulative percentage of number of items and the cumulative percentage of expenditure were also calculated. This list was then subdivided into three categories: $\mathrm{A}, \mathrm{B}$, and $\mathrm{C}$, based on the cumulative cost percentage of $70 \%, 20 \%$, and $10 \%$, respectively. ${ }^{11}$ The $\mathrm{ABC}$ analysis was used to obtain consumption value and investment value in both pharmacies.

\section{Results and Discussion}

Based on the interview with staffs, inventory planning in the pharmacies (Pharmacy $\mathrm{X}$ and $\mathrm{Y})$ were arranged by previous data. While in the procurement process, ordering the drug was conducted through the application of drug management information system (SIMO) by placing drug order within the application.

In the drug procurement process, drugs order were placed by the application, the drugs then were selected based on the ABC analysis method by identifying wether the drug is slow moving, moderate, or fast moving. Thereby, the procurement activity was effectively executed based on the pattern of the drug consumption in the pharmacies at surrounding area, then the sales target will be achieved. In the procurement process, the quantity and nominal items invested, and selling frequency of each drug per month are need to be considered.

Moreover, buffer stock should be also considered, thus, the drug that out of stock can be avoided and all transactions can be well executed. Buffer stock for drug included in the pareto $\mathrm{A}, \mathrm{B}$ and $\mathrm{C}$ is for 7,6 , and 5 days, respectively. However, if out of stock is still occur in the pharmacies $\mathrm{X}$ and $\mathrm{Y}$, as the mitigation procedure the pharmacy could ask or buy the item from other pharmacies to overcome the unavailable item, but actually the action should be avoided as much as possible. Therefore, $\mathrm{ABC}$ analysis method is necessary to be implemented in the procurement activity in avoiding drug unavailability.

According to Suciati and Adisasmito, drug procurement budgeting is also essential 
Table 1. Consumption Value of the Pharmacy Store 1

\begin{tabular}{ccccc}
\hline Groups & $\begin{array}{c}\text { Number of } \\
\text { Consumptions }\end{array}$ & $\begin{array}{c}\text { Consumption } \\
(\mathbf{\%})\end{array}$ & $\begin{array}{c}\text { Number of } \\
\text { Drug Items }\end{array}$ & $\begin{array}{c}\text { Drug Items } \\
\mathbf{( \% )}\end{array}$ \\
\hline A & 102,349 & 81.78 & 83 & 26.43 \\
B & 14,616 & 11.68 & 102 & 32.48 \\
C & 8,185 & 6.54 & 129 & 41.09 \\
Total & 125,150 & 100.00 & 314 & 100.00 \\
\hline
\end{tabular}

Table 2. Consumption Value of the Pharmacy Store 2

\begin{tabular}{ccccc}
\hline Groups & $\begin{array}{c}\text { Number of } \\
\text { Consumptions }\end{array}$ & $\begin{array}{c}\text { Consumption } \\
(\%)\end{array}$ & $\begin{array}{c}\text { Number of } \\
\text { Drug Items }\end{array}$ & $\begin{array}{c}\text { Drug Items } \\
(\%)\end{array}$ \\
\hline A & 51,705 & 60.00 & 87 & 27.10 \\
B & 21,674 & 25.16 & 100 & 31.15 \\
C & 12,768 & 14.94 & 134 & 41.75 \\
Total & 86,147 & 100.00 & 321 & 100.00 \\
\hline
\end{tabular}

to be considered in the drug procurement activity. ${ }^{16}$ It is supported by a published study conducted by Rumbay et al., which stated that the lack of appropriate drug procurement budget indirectly resulted in a decrease in the suitability of drug availability. ${ }^{17}$ Hence, the $\mathrm{ABC}$ analysis method is needed to evaluate drug planning and procurement so that budget efficiency could be achieved.

Based on this study result, the consumption reports in the 2019 showed that number of drug items listed in private healthcare insurance recorded in January to December 2019 in the pharmacies $\mathrm{X}$ and $\mathrm{Y}$ were 314 and 321, respectively. The results of $\mathrm{ABC}$ analysis method based on consumption value are presented in Table 1 and 2.

Based on the $\mathrm{ABC}$ analysis method result in both of pharmacies, drug listed in the group A showed the highest consumption value but had the lowest number of items. The high value of consumption is necessary to be concerned to avoid out of stock drugs listed in $\mathrm{Z}$ insurance formularium. The inventory drugs availability in group B need to be carefully maintained, while drugs in group $\mathrm{C}$ can be the main choice for reduction in procurement, to prioritize the need for other drugs that are very high in the community.

This results were similar to the previous study, which conducted the effectiveness of $\mathrm{ABC}$ analysis in the planning of JKN drugs in the Puskesmas in Madiun. The study showed the highest consumption value owned by the group A with 20,600 items but covers the lowest number of items of all items with $15.9 \%$, while group B with 7,100 items but accounted for $20.5 \%$ of the whole drug and group $\mathrm{C}$ with 3,725 items with $63.6 \%$ number of items from the total items. ${ }^{13}$ Therefore, in the present study, the drug included in group A needs more attention to be controlled to avoid greater losses either for the pharmacies or the health center. Group A items must be appropriately maintained, specifically in the planning and procurement process. The results of $\mathrm{ABC}$ analysis based on investment value of pharmacy $\mathrm{X}$ and $\mathrm{Y}$ are presented in Table 3 and 4. 
Table 3. Investment Value of Pharmacy Store 1

\begin{tabular}{ccccc}
\hline Groups & $\begin{array}{c}\text { Investment } \\
\text { Amounts (Rp) }\end{array}$ & $\begin{array}{c}\text { Cost } \\
(\mathbf{\%})\end{array}$ & $\begin{array}{c}\text { Number of } \\
\text { Drug Items }\end{array}$ & $\begin{array}{c}\text { Drug Items } \\
\mathbf{( \% )}\end{array}$ \\
\hline A & $59,894,907$ & 86.38 & 83 & 26.43 \\
B & $67,715,163$ & 9.80 & 102 & 32.48 \\
C & $26,443,926$ & 3.83 & 129 & 41.09 \\
Total & $691,053,996$ & 100.00 & 314 & 100.00 \\
\hline
\end{tabular}

Table 4. Investment Value of Pharmacy Store 2

\begin{tabular}{ccccc}
\hline Groups & $\begin{array}{c}\text { Investment } \\
\text { Amounts (Rp) }\end{array}$ & $\begin{array}{c}\text { Cost } \\
\mathbf{( \% )}\end{array}$ & $\begin{array}{c}\text { Number of } \\
\text { Drug Items }\end{array}$ & $\begin{array}{c}\text { Drug Items } \\
\mathbf{( \% )}\end{array}$ \\
\hline A & $1,060,119,878$ & 89.62 & 87 & 27.10 \\
B & $90,114,052$ & 7.62 & 100 & 31.15 \\
C & $32,690,607$ & 2.76 & 134 & 41.75 \\
Total & $1,182,924,537$ & 100.00 & 321 & 100.00 \\
\hline
\end{tabular}

Previous study showed that based on $\mathrm{ABC}$ analysis, investment value of JKN drug in group A with the highest value (70.9\%), then followed by group B (19.7\%), and the lowest investment value is in group C $(9.4 \%) .{ }^{13}$ In the present study, it can be understood that drug in group A had the highest investment value or the highest budget intake, thus, it needed to be controlled intensively by generating consumption reports in detail, recording the stocks in the stock card, and monitoring SIMO application regularly. ${ }^{18}$ Therefore, the storage must be carried out strictly in order to avoid possible loss of inventory. While drug controlling for group B drug is not as strict as in group $\mathrm{A},{ }^{19}$ nevertheless, detail of consumption report is also needed to be monitored periodically in once a month or every twice a month.

Stock for drug listed in group A and B should be kept as low as possible to facilitate easier controlling, but still the supply must be maintained to meet the needs of pharmaceutical care services. Meanwhile, drug controlling in group $\mathrm{C}$ drug which absorbed the smallest budget in procurement can be recorded and reported by monitoring of every 2 to 6 months. In supporting this study, according to a published study that higly efficient procurement process will ultimately demand smaller budget in the drug costs either in the pharmacies or the health center. ${ }^{20}$

Drugs included in group $\mathrm{C}$ showed the largest number of drug items and had less investment value, hence it is necessary to eliminate drug items with lower consumption, ${ }^{18}$ especially for unsold drugs during the year but the supplies still excessive, generally, the drug could be returned or replaced.

According to a published study conducted by Flores et al., the drug controlling system using the $\mathrm{ABC}$ analysis method needs to be reviewed periodically due to the changes in prices and consumption that are influenced by trend of diseases and seasons. ${ }^{18}$ Evaluation of the ABC analysis can be carried out annually together with the establishment of standard drug lists and the preparation of an annual budget plan either in the pharmacies or the health center. 


\section{Conclusion}

Based on the study of inventory control using $\mathrm{ABC}$ analysis method in planning and procurement activities of drug listed in the formularium of $\mathrm{Z}$ insurance in the pharmacies $\mathrm{X}$ and $\mathrm{Y}$ in 2019 located in Tangerang Selatan, Banten, could be concluded that drug listed in group A showed the highest consumption and investment value that are needed to be controlled intensively. Through drug controlling system using the $\mathrm{ABC}$ analysis that is periodically reviewed could assist pharmacies in planning and procurement activities based on the priority of the drug, taking into account the values of consumption and investation are obtained.

\section{References}

1. Anand T, Ingle GK, Kishore J, Kumar R. ABC-VED analysis of a drug store in the Department of Community Medicine of a Medical College in Delhi. Indian Journal of Pharmaceutical Sciences. 2013 Jan;75(1):113-7

2. Devnani M, Gupta AK, Nigah R. ABC and VED analysis of the pharmacy store of a tertiary care teaching, research and referral healthcare institute of India. Journal of Young Pharmacist. 2010 Apr;2(2):201-5.

3. Pund S, Kuril B, Hashmi S, Doibale M, Doifode S. ABC-VED matrix analysis of Government Medical College, Aurangabad drug store. International Journal of Community Medicine and Public Health. 2016;3(2).

4. Migbaru S, Yigeremu M, Woldegerima B, Shibeshi W. Original article ABCVEN matrix analysis of pharmaceutical inventory management in Tikur Anbessa Specialized Hospital for the years 2009 to 2013 , Addis Ababa , Ethiopia. Indian Journal of Basic and Applied Medical Research. 2016;5(2):734-743.

5. Kementerian Kesehatan Republik Indonesia. Peraturan Menteri Kesehatan
Republik Indonesia Nomor 73 Tahun 2016 Tentang Standar Pelayanan Kefarmasian Di Apotek. Menteri Kesehatan Republik Indonesia; 2016.

6. Dwivedi S, Kumar A, Kothiyal P. Inventory Management: A Tool of Identifying Items That Need Greater Attention for Control. Pharma Journal. 2012;1(7):125-129.

7. Mehrotra S, Basukala S. Management of Drugs using 3D Music Inventory Control Technique in a Tertiary Care Hospital. International Journal of Current Research. 2015;7(04):15219-15223.

8. Oberoi S, Oberoi A. Pharmacoeconomics guidelines: The need of hour for India. International Journal of Pharmaceutical Investigation. 2014;4(3):109.

9. Vollmann T, Berry W, Whybark DC, Jacobs FR. Manufacturing Planning and Control Systems for Supply Chain Management. The Definitive Guide for Professionals; 2004.

10. National institute of Health \& Family Welfare, New-Delhi Module. Materials management (procurement and equipment management). In: Theme I: Block 4. ; 2009.

11. Abdelmonim Ahmed H, I. Kheder S, Mohamed Awad M. Pharmaceutical inventory control in Sudan central and hospital stores using ABC-VEN analysis. Global Drugs and Therapeutics. 2019;4(2):1-6.

12. Abdillah AD, Rahmiyati AL, Fitria I. Analysis of Medicine Control Based on Abc Method in the Cibereum Puskesmas Hilir, Sukabumi City in 2019. Third International Seminar Global Health (3rd ISGH) Technology Transform Healthcare a Better Life. 2019;3(1):79-82.

13. Bachrun E. Efektifitas Metode ABC (Activity Based Costing) Dalam Analisis Perencanaan Obat JKN di Puskesmas Dagangan Kabupaten Madiun. Jurnal Kesehatan. 2017;8(2):250. 
14. Pujawati H. Analisis Sistem Pengadaan Obat dengan Metode ABC Indeks Kritis. Skripsi. 2015

15. Wahyuni T. Penggunaan Analisis ABC untuk Pengendalian Persediaan Barang habis Pakai: Studi Kasus di Program Vokasi UI. Jurnal Vokasi Indonesia. $2015 ; 3 ;(2)$.

16. Suciati S, Adisasmito WBB 2006. Analisis Perencanaan Obat Berdasarkan ABC Indeks Kritis di Instalasi Farmasi. Jurnal Manajemen Pelayanan Kesehatan. 2006;09(1):19-26.

17. Rumbay IN, Kandou GD, Soleman T. Analisis Perencanaan Obat di Dinas Kesehatan Kabupaten Minahasa Tenggara. Jikmu. 2015;5(2b):469-478.

18. Flores SFL De, Pribadi F, Risdiani I. Analisis Perencanaan Persediaan Obat dengan Menggunakan Metode ABC Indeks Kritis di Instalasi Farmasi RSU PKU Muhammadiyah Bantul. International Journal of Ecomics, Business Management Research. Published online 2017.

19. Seto S, Nita Y, Triana L. Manajemen Farmasi: Apotek, Farmasi, Rumah Sakit, Pedagang Besar Farmas, Industri Farmasi. Airlangga University Press, Surabaya; 2004.

20. Nur AK, Kautsar AP, Hilmi IL, Abdulah R. Efficiency Fast-Moving Drug Plan with Reorder Point Intervention at a Private Hospital in Bandung. Pharmacology and Clinical Pharmacy Research. 2019;4(3). 